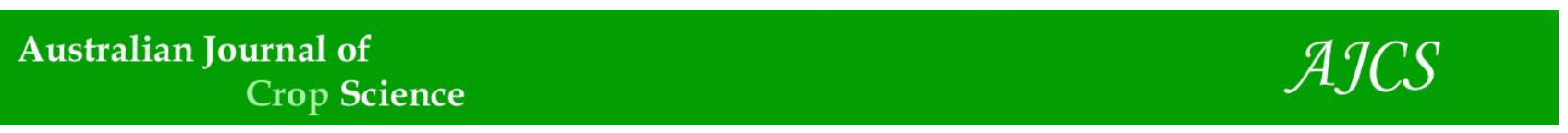

AJCS 13(06):976- 987 (2019)

ISSN:1835-2707

doi: 10.21475/ajcs.19.13.06.p1767

\title{
Physiological tolerance to drought under high temperature in soybean cultivars
}

\author{
Jônatas Neves de Castro, Caroline Müller, Gabriel Martins Almeida, Alan Carlos Costa* \\ Ecophysiology and Plant Productivity Laboratory, Goiano Federal Institute of Science and Technology- Campus Rio \\ Verde, P.O. box 66, 75901-970, Rio Verde, GO, Brazil
}

*Corresponding author: alan.costa@ifgoiano.edu.br

\begin{abstract}
Soybean is one of the most economically important crops and has experienced adverse physiological and biochemical effects when subjected to drought stress and heat, resulting in lost productivity. Thus, the objective of this work was to evaluate the physiological, metabolic and growth responses of well-watered and drought-treated soybean cultivars under high temperature. The experimental design was set up in randomized blocks, in a factorial scheme with three soybean cultivars (7739 M, Anta 82 and Desafio) and two water levels ( $100 \%$ and $40 \%$ field capacity). The experiment was conducted in a controlled growth chamber with a gradual rise in temperature at $41^{\circ} \mathrm{C}$ for 5 hours daily. Morpho-physiological and metabolic analyses were performed 12 days after the treatments imposition. The parameters of water and osmotic potentials, relative water content, photosynthetic rate, stomatal conductance, transpiratory rate, electron flux for the carboxylation and oxygenation of RuBisCO were decreased for all cultivars under water deficit and high temperature. The results showed that the photorespiration and the rate of electrolyte leakage were increased as well. These results showed that these physiological behaviors are standard for soybean plants under water deficit, regardless of cultivars. The cultivars $7739 \mathrm{M}$ and Desafio showed lower performance than the cultivar Anta 82 for the parameters of total electron flow and effective quantum yield of PS II. The $7739 \mathrm{M}$ and Anta 82 were the only cultivars to show increased nonphotochemical quenching dissipation and total soluble sugar content, respectively, under stress conditions. Desafio cultivar demonstrated greater physiological and growth traits stability, which could potentially indicate double tolerance to these stresses.
\end{abstract}

Keywords: cross tolerance; Glycine max (L.); global warming; heat waves; water stress.

\section{Introduction}

Soybean (Glycine max (L.) Merrill) is one of the most economically important crops in the world. The central west region is the largest producer in Brazil (Conab, 2016). This region has a mean annual precipitation of 1200 to $1800 \mathrm{~mm}$, which is concentrated in the spring and summer seasons. However, even during the rainy season, short periods of water deficit and heat waves can occur (Marcuzzo et al., 2012). This climatic instability has not only intensified in Brazil (Conab, 2016), but also on a global scale. It is adversely affecting plant development in many agricultural areas (Dai et al., 2018).

Water deficit promotes the reduction of leaf water potential, leading to stomatal closure, decreased $\mathrm{CO}_{2}$ absorption, and reduced photosynthesis (Goisser et al., 2016; Batista et al., 2018; Moura et al., 2018). In addition, water deficit increases foliar temperature (Heschel et al., 2014), affects membrane properties, and decreases dry matter production, leading to premature senescence and causing reduced production (Arruda et al., 2015; Fernandes et al., 2015). High temperature combined with water deficits has been a frequent phenomenon due to the global warming (Gondim et al., 2010; Lubovská et al., 2014; Perdomo et al., 2017). High temperatures have generally occurred in heat waves, which are characterized by temperatures above the historical average of a given period (Zuo et al., 2015; Qu et al., 2016). However, these combined stresses can occur in tropical regions even without heat waves, especially in the summer.

The isolated effects of high temperatures include altering the plants photosynthetic capacity, particularly by affecting membrane permeability, reducing the content of chloroplastidic pigments, and disrupting electron transport (Ashraf and Harris, 2013; Lu et al., 2017; Mishra et al., 2017). This disruption induces the formation of reactive oxygen species (ROS), which may promote photo-inhibition, as well as inactivation of Calvin cycle proteins and enzymes (Mathur et al., 2014). The plant damage can also be exacerbated by combined drought and high temperature stresses, causing substantial losses in many agricultural areas (Arruda et al., 2015; Harsh et al., 2016). According to Silva et al. (2010), the combined effects promote greater production of ROS, lower $\mathrm{CO}_{2}$ assimilation, and photochemical activity due to lower stomatal conductance in comparison to the individual stresses (Silva et al., 2010; Nankishore and Farrell, 2016). Therefore, elucidation of the plant strategies that confer tolerance to both drought and high temperature stresses is crucial to reduce productivity losses in soybean crops ( $\mathrm{Li}$ et al., 2013).

Several mechanisms are involved in the maintenance of plant growth, such as water use efficiency and osmotic adjustment. They are considered important characteristics in the search for plants that are tolerant to the combined stress of drought and high temperature since they help 
reduce water loss (Messinger et al., 2006; Du et al., 2009). Osmotic adjustment occurs in an adaptive mechanism to maintain the water potential $\left(\Psi_{\mathrm{w}}\right)$ of plant cells and their turgor (Pintó-Marijuan and Munné-Bosch, 2013; Wu et al., 2014). Even under water restriction, this adjustment allows the plant to keep the stomata partially open to assimilate $\mathrm{CO}_{2}$ and continue the processes of cell elongation and plant growth (Araújo and Deminicis, 2009; Monteiro et al., 2014). In order to allow osmotic adjustment, tolerant plants accumulate osmotically active compounds such as polyamines, glycine, organic acids, calcium, potassium, chloride ions, proline, sugars, and polyols, particularly sucrose (Cvikrová et al., 2013; Khan and Komatsu, 2016; Batista et al., 2018). Along with high efficiency in osmotic adjustment and water use, the ability to maintain photosynthetically active structures is also important for the selection of soybean cultivars with double tolerance to stresses caused by water deficit and high temperature.

Several studies have indicated that synergistic effects between water deficit and high temperature intensify metabolic and physiological damage, and consequently the crop yield of beans (Araújo and Deminicis, 2009), cotton (Carmo-Silva et al., 2012), and wheat (Pradhan et al., 2012). Thus, understanding the physiological processes that regulate the double tolerance to water deficit and high temperature is important to characterize the defense responses and is crucial for cultivar selection (Ding et al., 2015; Zhang et al., 2015).

Considering this information, we tested the hypotheses: (1) combined water deficit and high temperature stresses intensify the morphological damage in soybean cultivars, and (2) physiological and morphological characteristics are good indicators for selecting soybean cultivars that are double tolerant to drought and heat. This work evaluates the morpho-physiological and metabolic responses of commercial soybean cultivars subjected to water deficit and high temperature

\section{Results}

\section{Water relations and leaf temperature}

In all cultivars under water deficit, the water potential $\left(\Psi_{\mathrm{W}}\right)$ and the leaf $\left(\Psi_{\mathrm{S}_{\text {leaf }}}\right)$ and root $\left(\Psi_{\mathrm{S}_{\text {root }}}\right)$ osmotic potential decreased by $55 \%, 28 \%$, and $36 \%$ on average, respectively (Fig. 1A-C). Relative water content of leaves (RWC) was decreased by $10 \%$ regardless of cultivar (Fig. 1D). The leaf temperatures evaluated under growth chamber conditions of 25 and $41^{\circ} \mathrm{C}$ showed no differences between cultivars and water treatments (Supplementary Fig. S1). However, the absolute value of leaf temperature was $4.1^{\circ} \mathrm{C}$ higher on average than the growth chamber temperature in the early morning (Supplementary Fig. S1A). When the growth chamber temperature reached $41^{\circ} \mathrm{C}$, the leaf temperature was around $3.6^{\circ} \mathrm{C}$ below the chamber temperature (Supplementary Fig. S1B).

\section{Gas exchange}

Gas exchange was differentially affected by the water stress and high temperature in function of different cultivars. The photosynthetic rate $(A)$ did not differ among the cultivars, only for the water treatments, in which well-watered plants (100\% FC) showed higher values (Fig. 2A). Cultivar $7739 \mathrm{M}$ showed a significantly increased stomatal conductance $\left(g_{\mathrm{s}}\right)$, transpiration rate $(E)$, ratio between internal and external $\mathrm{CO}_{2}$ concentrations $\left(C_{i} / C_{a}\right)$, and respiration $\left(R_{\mathrm{n}}\right)$ when compared to the Anta 82 and Desafio cultivars, independent from water treatment (Fig. 2B-D and 2F). The $g_{\mathrm{s}}$ and $E$ also differed for water treatments, with higher values in wellwatered plants (Fig. 2B and 2C). In addition, the efficiency of water use (WUE) was lower for cultivar $7739 \mathrm{M}$ and higher in the Anta 82 and Desafio cultivars (Fig. 2E).

\section{Chlorophyll (a) fluorescence}

The maximum PSII quantum yield $\left(F_{\mathrm{v}} / F_{\mathrm{m}}\right)$ was differed only among cultivars, with Anta 82 and Desafio showed higher values than $7739 \mathrm{M}$ (Fig. 3A-B). The minimal chlorophyll fluorescence $\left(F_{0}\right)$ did not show differences between cultivars and water treatments (Fig. 3C-D). The interaction among cultivars and water treatments was significant for the quantum yield of photochemical energy conversion PSII ( $\left.Y_{\text {II }}\right)$ and the electron transport rate $(E T R)$, with decreased by $18 \%$ in cultivar $7739 \mathrm{M}$ and $9 \%$ in cultivar Desafio under water deficit compared to well-watered plants (Fig. 3E-F and $3 G-H)$. There was no difference between the treatments for the yield of non-regulated energy dissipation ( $Y_{\mathrm{NO}}$ ) (Fig. 3I-J). However, the interaction was significant for the yield of regulated energy dissipation $\left(Y_{\mathrm{NPQ}}\right)$, with increased $24 \%$ in cultivar $7739 \mathrm{M}$ under water deficit (Fig. 3K-L).

\section{Electron flow and photorespiration}

The total electron flow $\left(J_{\mathrm{T}}\right)$ was decreased by $17 \%$ in the cultivar $7739 \mathrm{M}$ under water deficit (Fig. 4A). The electron flow to carboxylation $\left(J_{C}\right)$ was differed only in water treatment and the higher values were observed for wellwatered plants (Fig. 4B). The electron flow to oxygenation $\left(J_{\mathrm{O}}\right)$ and the rate of $\mathrm{CO}_{2}$ produced by photorespiration $\left(P_{\mathrm{R}}\right)$ differed separately for cultivars and water treatment. Anta 82 and Desafio cultivars showed higher $J_{\mathrm{O}}$ and $P_{\mathrm{R}}$ compared to cultivar $7739 \mathrm{M}$ (Fig. $4 \mathrm{C}$ and $4 \mathrm{E}$ ). Cultivars $7739 \mathrm{M}$ and Anta 82 also showed higher $J_{C} / J_{T}$ ratios (Fig. 4D). The $P_{R} / A$ ratio did not differ for cultivars and between water treatments (Fig. 4F).

\section{Photosynthetic pigments and membrane permeability}

The interaction was not significant for the photosynthetic pigments. However, chlorophyll $a(\mathrm{Chl} a)$ and carotenoids differed only among cultivars and the highest contents were observed for cultivar Desafio, followed by Anta 82 (Fig. 5A and $5 \mathrm{C})$. The content of chlorophyll $b(\mathrm{Chl} b)$ did not differ as a function of treatments (Fig. 5B). The rate of electrolyte leakage (REL) was increased in cultivars $7739 \mathrm{M}$ and Anta 82, but higher REL values were observed for cultivar $7739 \mathrm{M}$, independent of the water treatment (Fig. 5D). In addition, there were difference between water treatments, whereas higher REL was occurred in plants under water deficit $(40 \%$ FC).

\section{Sugars, starch and proline content}

The total soluble sugars (TSS) and non-reducing sugars (NRS) were higher in Anta 82 compared to the other cultivars under combined stress and TSS (16\%) was increased compared to well-watered plants (Fig. 6A and 6B). Under water deficit, there was a reduction in TSS (24\%) and NRS (21\%) for cultivar Desafio, compared to irrigated plants. The 
starch (Sta) concentration was differed only among cultivars, because the interaction was not significant, with higher values for Anta 82 and Desafio cultivars, respectively (Fig. $6 \mathrm{C}$ ). The proline (Pro) concentration was higher for the irrigated Desafio cultivar, but when subjected to the water deficit under high temperature, it was decreased by $40 \%$ (Fig. 8D).

\section{Plant growth parameters}

The leaf area (LA) was reduced in 7739 M (19\%), Anta 82 (29\%) and Desafio (14\%), when exposed to water deficit (Supplementary Fig. S2A). The specific leaf area (SLA) was increased in plants under water deficit, independent of cultivars (Supplementary Fig. S2C). In $7739 \mathrm{M}$ and Anta 82 cultivars, there was a reduction of $39 \%$ and $51 \%$ for leaf dry matter (LDM) and the number of nodes (NN) by 19 and $31 \%$, respectively (Supplementary Fig. S2C and S2E). Reductions in stem diameter (DM) and stem dry matter (SDM) were also observed as a function of treatments with water, once the interaction was not significant and there was no difference between the cultivars (Supplementary Fig. S2D and S2F). Cultivar $7739 \mathrm{M}$ showed higher plant height $(\mathrm{H})$ among the cultivars (Supplementary Fig. S2G).

\section{Discussion}

The behavior of the photosynthetic mechanism in response to the combined water and thermal stresses differed in soybean cultivars. Gas exchange was more altered in cultivar $7739 \mathrm{M}$ under combined stress. The reduction of net photosynthetic rate $(A)$ is possibly related to changes in the carboxylic efficiency of RuBisCO. This can be proved by maintaining the $C_{i} / C_{a}$ ratio and reduction of electron flow used for RuBisCO carboxylation $\left(J_{C}\right)$, in all cultivars.

The decrease in the activity, inactivation, or denaturation of RuBisCO has been suggested as one of the factors responsible for the decrease of photosynthetic efficiency in plants exposed to high temperatures (Marthur et al., 2014; Szymańska et al., 2017) and water stress (Silva et al., 2010; Carmo-Silva et al., 2012). These changes also promote accumulation of ATP and NADPH produced by ATPase in the photochemical stage of photosynthesis. This negatively affects the electron transport (Greer, 2015), as observed by reductions in $Y_{\|}$and ETR in $7739 \mathrm{M}$ and Desafio cultivars when exposed to combined stress. In addition, respiration $\left(R_{\mathrm{n}}\right)$ was lower for Anta 82 and Desafio cultivars; thus, contributing to lower carbon assimilation rates (Ribas-Carbo et al., 2005). However, no differences were observed for water treatments.

Total electron flow $\left(J_{T}\right)$ is considered a general state of photochemical activity (Bai et al., 2008; Silva et al., 2015). The decrease of $J_{T}$ in cultivars $7739 \mathrm{M}$ and Desafio is related to the decrease of $Y_{\| \mid}$and ETR. However, the electron flow to oxynenation $\left(J_{0}\right)$ was also decreased, indicating that the dissipation of surplus energy occurred via $Y_{\mathrm{NPQ}}$ (Fig. 3K-L). This thermal dissipation mechanism has been shown to be effective in preventing photo-inhibition under water deficit conditions (Silva et al., 2015). This can be confirmed by the maintenance of the $F_{\mathrm{v}} / F_{\mathrm{m}}$ ratio among water treatments, also observed by Silva et al. (2015) in Jatropha curcas plants. Thus, there was no request for an increase in $J_{0}$. By the other hand, the photorespiration was increased due to stomatal closure (Fig. 2B). This limitation to the gas exchange in function to the stomatal closure induced RuBisCO oxygenase activity, since the atmospheric $\mathrm{O}_{2}$ concentration is many times greater than that of $\mathrm{CO}_{2}$ (Santos et al., 2017).

The decrease of $J_{T}, J_{C}$ and $J_{O}$, without an increase of the electron flux attributed to RuBisCO oxygenation reactions and the rate of $\mathrm{CO}_{2}$ produced by photorespiration $\left(P_{\mathrm{R}}\right)$ in the cultivars, mainly Anta 82 and Desafio under combined stress. This indicates the binding of electrons to molecular oxygen and formation of reactive oxygen species (ROS), which are detrimental to cell membranes (Apel and Hirt, 2004; Gill and Tuteja, 2010). The increase in the rate of electrolyte leakage (REL), mainly in $7739 \mathrm{M}$ and Anta 82 cultivars (Fig. 5D), suggests the degradation of cell membranes, in monitoring damage to cell membranes in sunflower leaves (Vital et al., 2017). The ROS accumulation was not measured, but the increase in REL is a good indicator of lipid peroxidation and oxidant damage (Carvalho, 2008).

However, the oxidative damage observed by the increase of REL did not affect the efficiency of energy absorption by the antenna complex $\left(F_{0}\right)$. Although the lowest pigment content was observed for the cultivar $7739 \mathrm{M}$ and Anta 82 (Fig. 5A and $5 \mathrm{C}$ ), these differences were due only to the different characteristics of the cultivars, because there was no difference between the water treatments. Normally, the increase in $F_{0}$ is associated with damage to the reaction centers or energy dissipation via the antenna complex (Bolhar-Nordenkampf et al., 1989; Kumar et al., 2014). The stability and maintenance of the chloroplastidic pigments and consequently the antenna complex is required for an efficient photosynthetic process (DaMatta and Ramalho, 2006), especially under stress conditions. In soybean plants, as there was no difference between the water treatments, the maintenance in the carotenoid content of the cultivars can been described as a protective mechanism of energy excess in PS II, since it binds to singlet oxygen and minimizes ROS production (Ramel et al., 2012; Carmody et al., 2016).

In addition, quenching of regulated $\left(Y_{\mathrm{NPQ}}\right)$ and non-regulated $\left(Y_{\text {NO }}\right)$ non-photochemical dissipation mechanisms are used by plants to avoid photochemical damages, when they are exposed to water and thermal stress (Hendrickson et al., 2004; Kramer et al., 2004). The increase in $Y_{\mathrm{NPQ}}$ in cultivar $7739 \mathrm{M}$ under combined stress indicates thermal dissipation in the attempt to avoid oxidative stress and subsequent photoinhibition. According to Hetherington et al., (1998), the thermal dissipation is related to the acidification of the thylakoid lumen, which promotes the conversion of violaxanthin to zeaxanthin in the xanthophyll cycle and is responsible for the heat dissipation in the PSII (Kromdijk et al., 2016; Cardona et al., 2018). Unregulated energy dissipation protects against excess light energy absorption (Klughammer and Schreiber, 2008). Alternative energy dissipations; however, are protective mechanisms used as a first line of plant defense termed as a suppression mechanism (Kramer et al., 2004). The increase in $Y_{\mathrm{NPQ}}$ in cultivar $7739 \mathrm{M}$ under water deficit and the stability of $Y_{\mathrm{NO}}$ in all cultivars suggest that these mechanisms are dynamic and depend on the severity of the stress.

To prevent damage due to high temperature, the plants promote leaf cooling. In general, the cultivars decreased foliar temperature to $3.6^{\circ} \mathrm{C}$ below the ambient temperature $\left(41^{\circ} \mathrm{C}\right)$ (Supplementary Fig. S1B). The stomata opening for temperature regulation by leaf transpiration is a common response in well-watered plants exposed to high temperature (Mathur et al., 2014), which was observed through the high transpiration rate. This regulation aims to maintain the ideal temperature range for metabolic processes, 


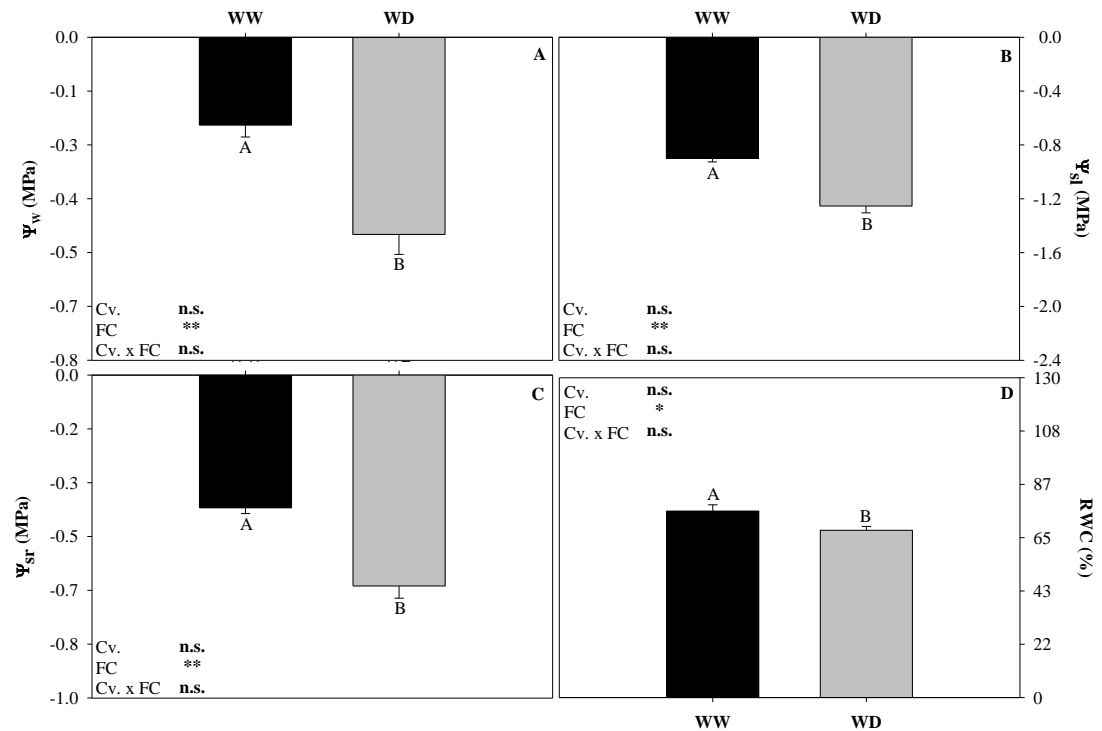

Fig 1. Predawn leaf water potential $\left(\Psi_{w}, \mathrm{~A}\right)$, leaf osmotic potential $\left(\Psi_{s l}, \mathrm{~B}\right)$, root osmotic potential $\left(\Psi_{s r}, \mathrm{C}\right)$ and relative water content of leaves (RWC, D), of soybean cultivars (CV.) under well-watered [WW, 100\% of the field capacity (FC)] and water deficit (WD, 40\% FC) treatments combined with high temperature after 12 days of the treatments. Bars represent means $\pm \operatorname{SE}(n=5)$. Data presented from the double factorial scheme according to the significance of ANOVA. The interaction between Cv. x FC was not significant (n.s.) for these parameters. Thus, means followed by the different uppercase letters between water treatments (FC factor) differ significantly from each other, as determined by Tukey's test ( ${ }^{*} p \leq 0.05$ and ${ }^{* *} p \leq 0.01$ ).

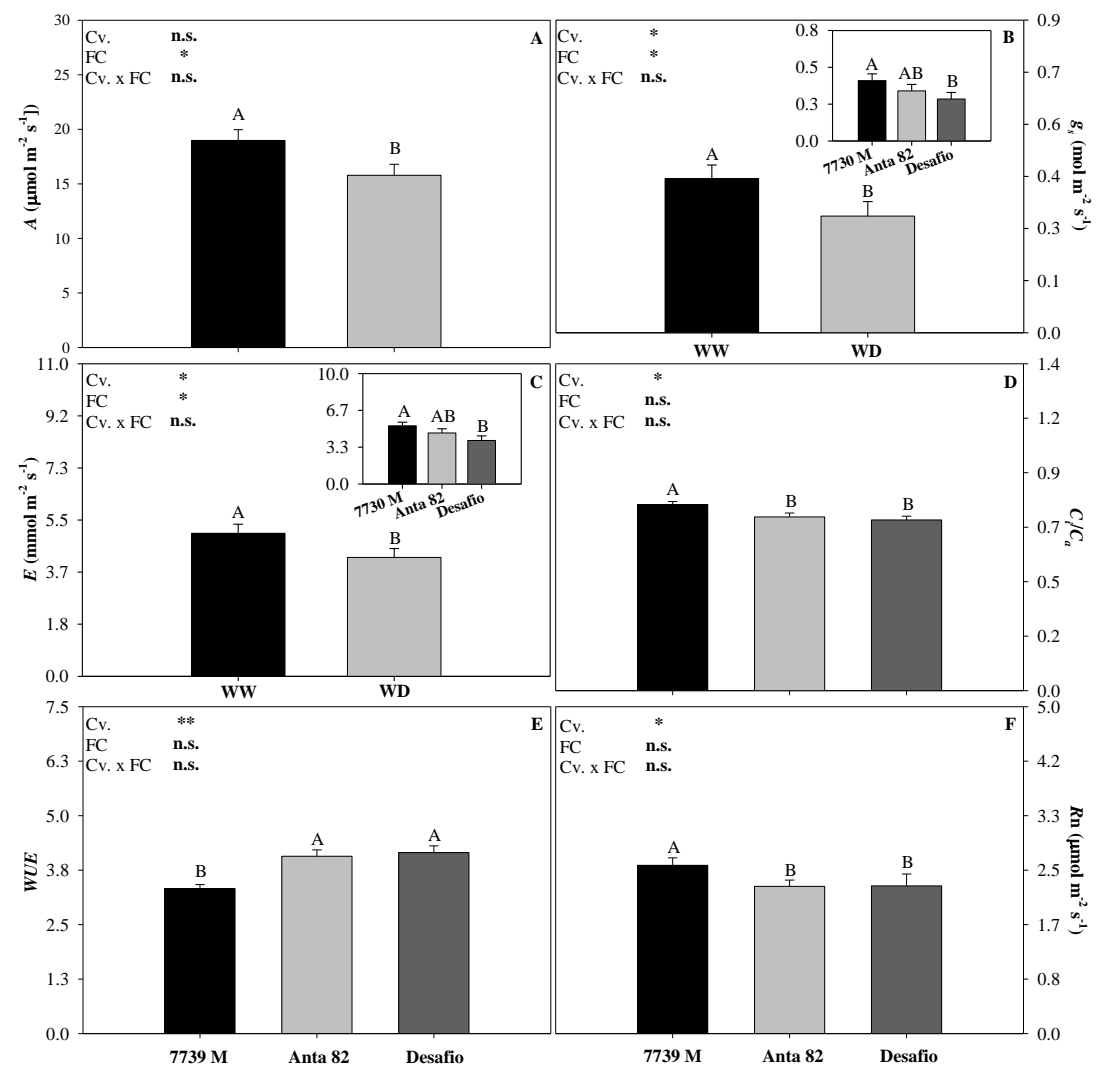

Fig 2. Net photosynthetic rate $(A, A)$, stomatal conductance $\left(g_{s}, \mathrm{~B}\right)$, transpiration rate $(E, C)$, ratio between internal and external $\mathrm{CO}_{2}$ concentration $\left(C_{i} / C_{a}, \mathrm{D}\right)$, water use efficiency $(W U E, \mathrm{E})$ and nocturnal respiration rate $\left(R_{\mathrm{n}}, \mathrm{F}\right)$ of soybean cultivars $(\mathrm{CV}$.) under wellwatered [WW, $100 \%$ of the field capacity (FC)] and water deficit (WD, $40 \% \mathrm{FC}$ ) treatments combined with high temperature after 12 days of the treatments. Bars represent means $\pm \operatorname{SE}(n=5)$. Data presented from the double factorial scheme according to the significance of ANOVA. The interaction between Cv. x FC was not significant (n.s.) for these parameters. Thus, means followed by the different uppercase letter among cultivars ( $\mathrm{Cv}$. factor) or water treatments (FC factor), differ significantly from each other, as determined by Tukey's test $\left({ }^{*} p \leq 0.05\right.$ and $\left.{ }^{* *} p \leq 0.01\right)$. 

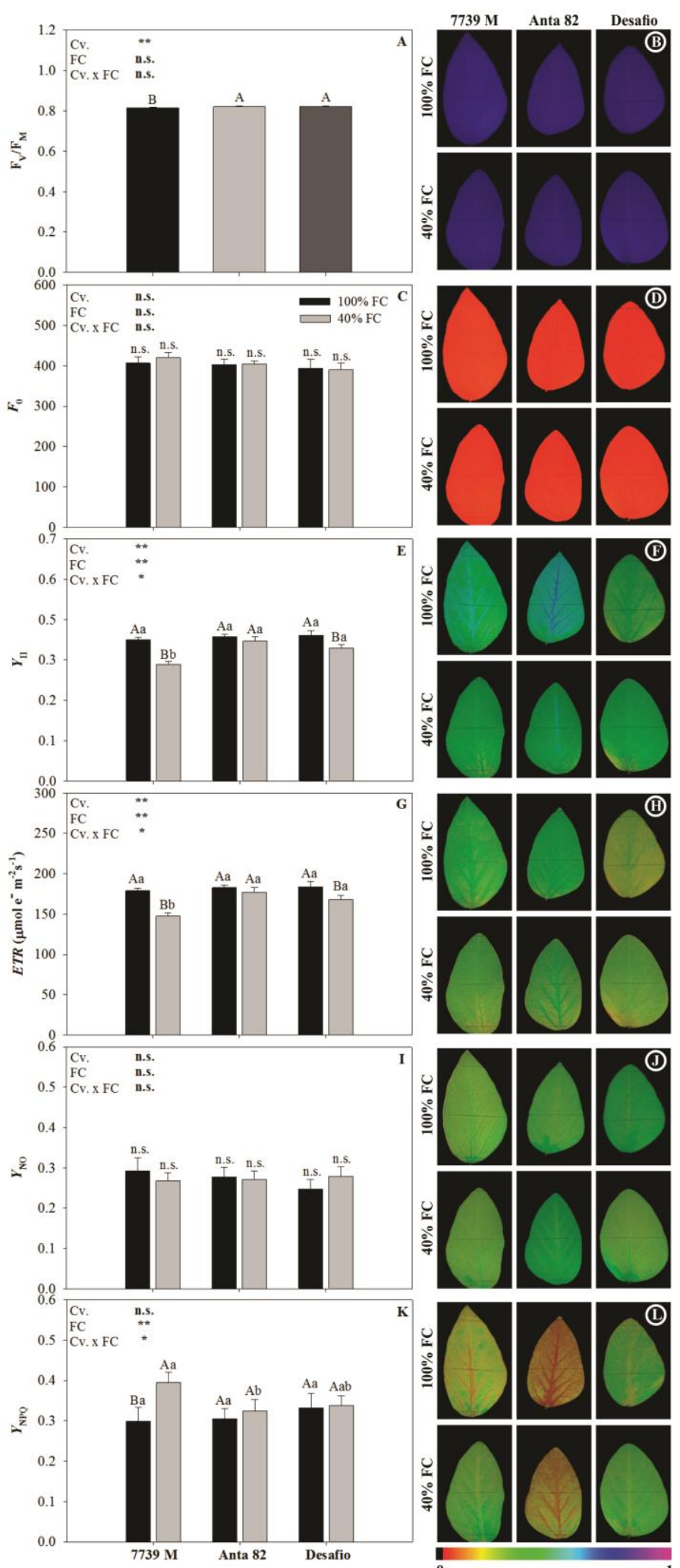

Fig 3. The maximum photochemical efficiency of PSII $\left(F_{\mathrm{V}} / F_{\mathrm{M}}, \mathrm{A}-\mathrm{B}\right)$, minimal fluorescence $\left(F_{0}, \mathrm{C}-\mathrm{D}\right)$, quantum yield of photochemical energy conversion in PSII $\left(Y_{\|}, \mathrm{E}-\mathrm{F}\right)$, electron transport rate $(E T R, \mathrm{G}-\mathrm{H})$, quenching of non-regulated $\left(Y_{\mathrm{NO}}, \mathrm{I}-\mathrm{J}\right)$ and regulated $\left(Y_{\mathrm{NPQ}}, \mathrm{K}-\mathrm{L}\right)$ non-photochemical dissipation of soybean cultivars ( $\mathrm{CV}$.) under well-watered [WW, $100 \%$ of the field capacity (FC)] and water deficit (WD, 40\% FC) treatments combined with high temperature after 12 days of the treatments. Bars represent means \pm SE $(n=$ 5). Data presented from the double factorial scheme according to the significance of ANOVA. Parameters wherein the interaction between CV. x FC was significant $\left({ }^{*}\right)$, means followed by the same letter, uppercase between water treatments and lowercase between cultivars, differ significantly from each other. On the other hand, parameters wherein the interaction (Cv. $x \mathrm{FC})$ was not significant (n.s.), means followed by the different uppercase letter among cultivars (Cv. factor), differ significantly from each other. The means were compared by the Tukey's test $\left({ }^{*} p \leq 0.05\right.$ and $\left.{ }^{* *} p \leq 0.01\right)$. The false color code depicted at the bottom of images ranges from 0.0 (black) to 1.0 (pink). 


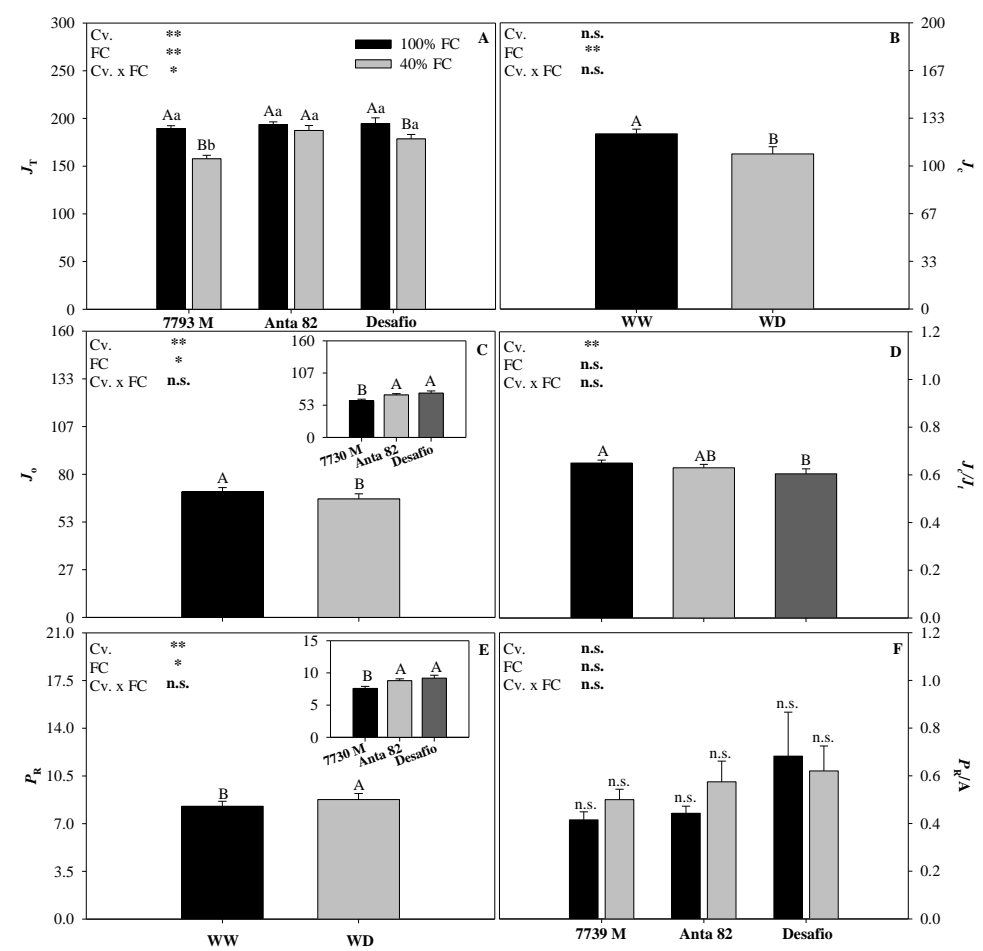

Fig 4. Total electron flow $\left(J_{T}, A\right)$, electron flow to carboxylation $\left(J_{C}, B\right)$, oxygenation $\left(J_{O}, C\right), J_{C} / J_{T}$ ratio $(D)$, photo-respiration $\left(P_{R}, E\right)$, and $P_{\mathrm{R}} / A$ ratio (F) of soybean cultivars (Cv.) under well-watered [WW, 100\% of the field capacity (FC)] and water deficit (WD, 40\% FC) treatments combined with high temperature after 12 days of the treatments. Bars represent means $\pm S E(n=5)$. Data presented from the double factorial scheme according to the significance of ANOVA. Parameters wherein the interaction between CV. $x$ FC was significant $\left({ }^{*}\right)$, means followed by the different letter, uppercase between water treatments and lowercase between cultivars differ significantly from each other. On the other hand, parameters wherein the interaction (Cv. x FC) was not significant (n.s.), means followed by the different uppercase letter among cultivars ( $\mathrm{Cv}$. factor) or water treatments (FC factor), differ significantly from each other. The means were compared by the Tukey's test ( ${ }^{*} p \leq 0.05$ and ${ }^{* *} p \leq 0.01$ ).

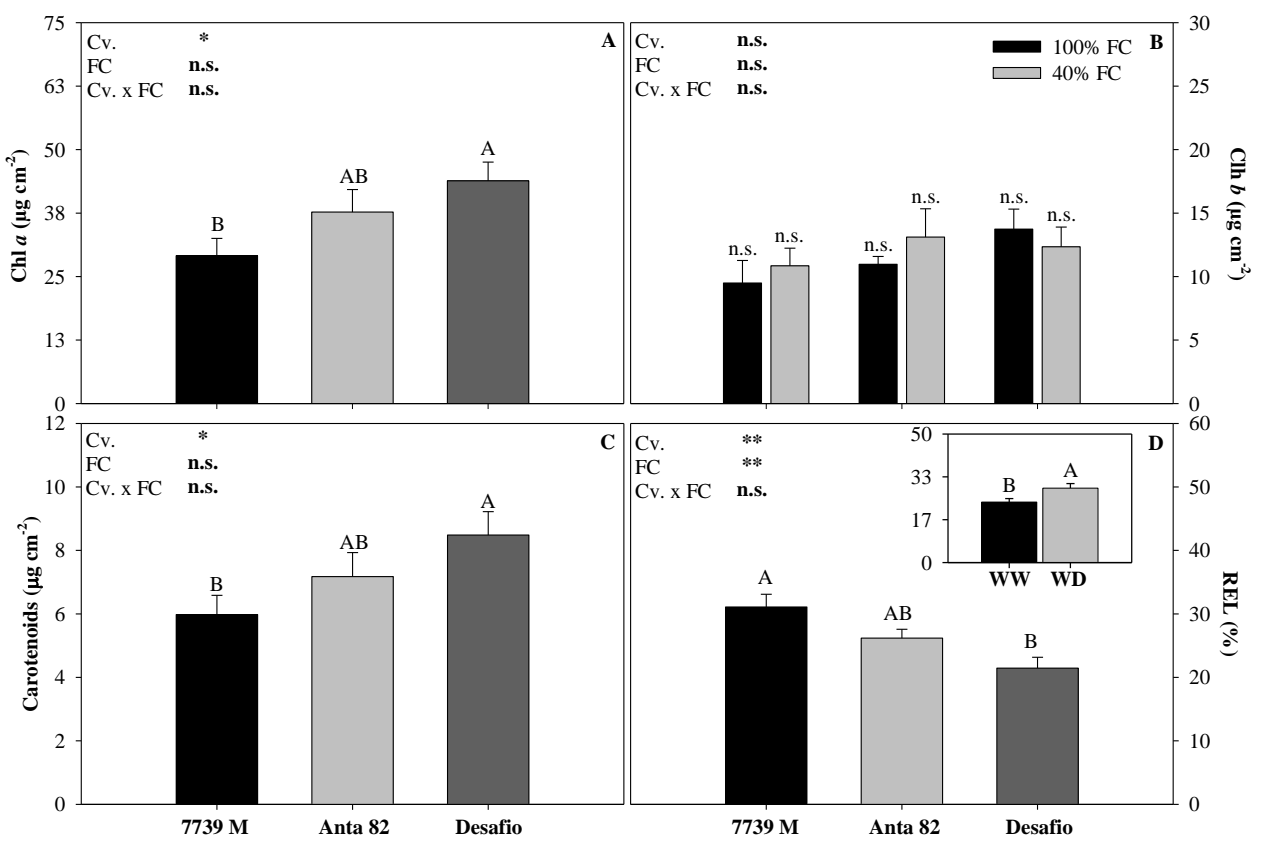

Fig 5. Chlorophyll $a(\mathrm{Chl} a, \mathrm{~A})$, chlorophyll $b(\mathrm{Chl} b, \mathrm{~B})$, carotenoids (C), and rate of electrolyte leakage (REL, D) of soybean cultivars (Cv.) under well-watered [WW, $100 \%$ of the field capacity (FC)] and water deficit (WD, $40 \% \mathrm{FC}$ ) treatments combined with high temperature after 12 days of the treatments. Bars represent means $\pm \operatorname{SE}(n=5)$. Data presented from the double factorial scheme according to the significance of ANOVA. The interaction between CV. x FC was not significant (n.s.) for these parameters. Thus, means followed by the different uppercase letter among cultivars (Cv. factor) or water treatments (FC factor), differ significantly from each other, as determined by Tukey's test ( ${ }^{*} p \leq 0.05$ and $\left.{ }^{* *} p \leq 0.01\right)$. 


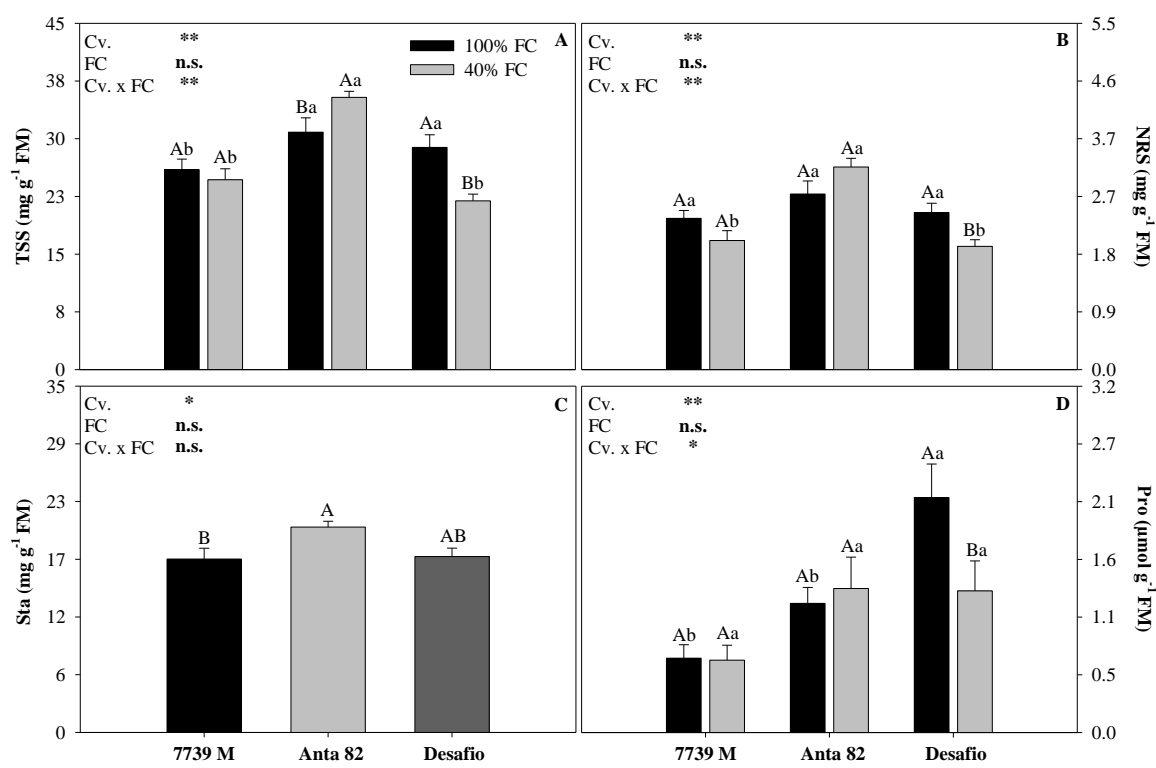

Fig 6. Total soluble sugars (TSS, A), non-reducing sugar (NRS, B), starch (Sta, C), and proline (Pro, D) of soybean cultivars (Cv.) under well-watered [WW, 100\% of the filed capacity (FC)] and water deficit (WD, 40\% FC) treatments combined with high temperature after 12 days of the treatments. Bars represent means $\pm S E(n=5)$. Data presented from the double factorial scheme according to the significance of ANOVA. Parameters wherein the interaction between $\mathrm{Cv}$. x FC was significant $\left(*\right.$ or $\left.{ }^{* *}\right)$, means followed by the different letter, uppercase between water treatments and lowercase between cultivars, differ significantly from each other. On the other hand, parameters wherein the interaction (Cv. x FC) were not significant (n.s.). Means followed by the different uppercase letter among cultivars ( $\mathrm{Cv}$. factor) differ significantly from each other. The means were compared by the Tukey's test ( ${ }^{*} p \leq 0.05$ and $\left.{ }^{* *} p \leq 0.01\right)$.

such as photosynthesis, and prevent cell damage and enzyme denaturation (Chaves et al., 2016), in addition to favoring $\mathrm{CO}_{2}$ input (Mathur et al., 2014) as a thermotolerance strategy.

The cultivars were able to maintain a high photosynthetic rate under well-watered conditions, but with reductions under water deficit. Associated with gas exchange measurements, the cultivars Anta 82 and Desafio present higher values of WUE, regardless of the water treatment. This was possible because of the regulation of the stomatal closure. In field conditions, considering the low WUE, the water soil can be depleted, resulting in severe damage, such as permanent wilting and consequent plant death (Han et al., 2016; Mckenzie-Gospsill et al., 2016).

One of the first responses to the water deficit is stomatal closure to avoid loss of water by transpiration (Pinheiro and Chaves, 2001; Silva et al., 2015). The stomata closure was observed in water deficit plants in all cultivars, demonstrating rapid mechanism to prevent dehydration. However, the reduction of $\Psi_{\mathrm{w}}$ and RWC indicates that stomatal regulation was not enough to avoid water loss. In this sense, the reduction of $\Psi_{s_{\text {leaf }}}$ and $\Psi_{s_{\text {root }}}$ observed in the three cultivars can be related to the accumulation of osmoregulatory compounds, which acts to maintain cellular turgor (Batista et al., 2018).

To increase or maintain the water plant status, osmolytes are synthetized, which reduce the leaf and root osmotic potential. Also, the osmotic adjustment is important for maintaining water uptake, $\mathrm{CO}_{2}$ assimilation, and growth (Araújo and Deminicis, 2009; Monteiro et al., 2014). Among the osmolytes, proline has been described to alleviate water stress (Díaz et al. 2005; Batista et al., 2018). However, under high temperature, sugars such as sucrose act in the osmoregulation since proline constitutes a toxic substance (Rizhsky et al., 2004).
In this study, the decrease in total soluble sugars (TSS), nonreducing sugars (NRS) and proline (Pro) that was observed along with water deficit under high temperature suggests that the osmotic potential is regulated by other compounds in cultivar Desafio. In cultivar Anta 82, there was an accumulation of TSS under combined stress, demonstrating a differential osmoregulatory mechanism. However, even with higher sugar accumulation and maintenance of photochemical efficiency, Anta 82 showed a reduced growth. The starch in plant metabolism acts according to the circadian clock, accumulating during the day and used at night (Zeeman et al., 2007). Wang et al. (2016) observed that during the day the concentration of starch in the leaves of cotton plants submitted to the water deficit is decreased, indicating that the sucrose transport and growth rate were reduced. However, in this study, starch (Sta) content in leaves among the cultivars did not differ as a function of water treatments. These results suggest that the Sta content was not affected by the water deficit.

$\mathrm{NN}$ is directly reflected on productivity since they emit new pods (Mundstock and Thomas, 2005). Under drought and heat stress conditions, the cultivar Desafio showed higher stability in NN, indicating greater production safety (Arruda et al., 2015). The increase in SLA under water deficit was directly associated with the lowest increases in LDM. In addition, all cultivars showed a decrease in diameter and stem dry matter. This suggests a greater allocation of biomass in other organs, such as roots. This is an important adaptive strategy for tolerating water stress (Hasibeder et al., 2015). On the other hand, considering the reduction in $A$, $Y_{\| 1}, E T R$ and growth, the cultivar $7739 \mathrm{M}$ demonstrated to be sensitive to the water deficit under high temperature. However, the cultivar Anta 82 showed reduction in NN even with greater stability in the gas exchange parameters, chlorophyll $a$ fluorecsence and REL than cultivar $7739 \mathrm{M}$. 
The evaluated morpho-physiological and metabolic characteristics are important for understanding the responses of soybean plants to water deficit and high temperature stresses and may contribute to the selection of tolerant cultivars.

\section{Materials and methods}

\section{Plant material and experimental conditions}

An experiment was performed in a growth chamber at the Ecophysiology and Plant Productivity Laboratory at the Goiano Federal Institute of Education, Science and Technology (IF Goiano), Rio Verde Campus (1 $17^{\circ} 48^{\prime} 07^{\prime \prime} \mathrm{S}$, $50^{\circ} 54^{\prime} 20^{\prime \prime} \mathrm{W}, 755-\mathrm{m}$ altitude). Soybean plants (Glycine max (L.) Merrill) were grown in polyethylene pots containing 12 $\mathrm{kg}$ of substrate. The substrate was prepared from a mixture of Red Latosol (LVdf) soil and sand at a ratio of 2:1, which was fertilized according to a chemical analysis of the soil and specific recommendations. Each pot contained a plastic base, and the soil was covered with a plastic film. Three soybean cultivars were used: 7739 M IPRO (Monsoy Seeds, São Paulo, Brazil), Anta 82 RR (Geneze Seeds, São Paulo, Brazil), and Desafio 8473 RSF (Brasmax Seeds, Cambé, Brazil). The conditions of the growth chamber were $\approx 65 \%$ relative humidity, irradiance of $\approx 650 \mu \mathrm{mol} \mathrm{m} \mathrm{m}^{-2}$, and temperatures of $25 / 20^{\circ} \mathrm{C}$ (day/night).

Treatments consisted of a combination of water deficit and high temperature applied at the $\mathrm{V}_{3}$ development stage (Fehr and Caviness 1977). The water deficit was determined by the gravimetric method, and two moisture levels were maintained: well-watered (WW, $100 \%$ of the field capacity $(\mathrm{FC})$ ) and water deficit (WD, 40\% FC). The high temperature was imposed by gradually increasing the temperature from ambient temperature at $10 \mathrm{~h}$ to $41 \pm 0.5^{\circ} \mathrm{C}$ at $12 \mathrm{~h}$. This condition was maintained for five hours and then gradually reduced to $20^{\circ} \mathrm{C}$ at around $7: 30 \mathrm{pm}$, which was maintained until a new cycle began on the next day (Supplementary Fig. S3). The evaluations were performed after 12 days of applying the combined stress.

\section{Water relations and leaf temperature}

Pre-dawn water potential $\left(\Psi_{\mathrm{w}}\right)$ was measured using a Scholander-type pressure chamber between $4 \mathrm{~h}$ and $6 \mathrm{~h}$. Cell solution was extracted to evaluate the osmotic potential of the leaf $\left(\Psi_{s_{\text {leaf }}}\right)$ and root $\left(\Psi_{s_{\text {root }}}\right)$ using an osmometer (VAPRO 5600 model, Elitech, France) according to Pask et al. (2012). The osmotic potential values were obtained using the Van't Hoff's equation:

$\Psi \mathrm{s}=-R \times T \times C s$

Where; $R$ is the universal gas constant $\left(0.08205 \mathrm{~L} \mathrm{~atm} \mathrm{~mol}^{-1}\right.$ $\left.\mathrm{K}^{-1}\right), T$ is the temperature in Kelvin $(T$ oK) and $C s$ the solute concentration $(\mathrm{M})$, usually expressed in atmospheres and converted to $\mathrm{MPa}(0.987 \approx 1 \mathrm{~atm}=0.1 \mathrm{MPa})$. The relative water content in leaves (RWC) was evaluated according Barrs and Weatherley (1962) with the formula:

$R W C(\%)=\frac{F M-D M}{T D-D M} X 100$

Where; FM is the fresh matter, TM is the turgid matter and $D M$ is the dry matter.

Leaf temperature of soybean plants was evaluated at $8 \mathrm{~h}$ and $13 \mathrm{~h}$ at 25 and $41^{\circ} \mathrm{C}$, respectively. A digital infrared thermometer (TI-920 model, Instrutherm, Brazil) was used for the determination of leaf temperature at a distance of $\approx 15 \mathrm{~cm}$ from the leaf blade.

\section{Physiological and biochemical evaluations}

\section{Gas exchange}

Gas exchange from G. max plants was measured in fully expanded leaves to determine the net photosynthetic rate $\left(A, \mu \mathrm{mol} \mathrm{CO} \mathrm{Cm}^{-2} \mathrm{~s}^{-1}\right)$, stomatal conductance $\left(g_{s}, \mathrm{~mol} \mathrm{H}_{2} \mathrm{O} \mathrm{m}\right.$ $\left.\mathrm{s}^{-1}\right)$, transpiration rate $\left(E, \mathrm{mmol} \mathrm{H}_{2} \mathrm{O} \mathrm{m} \mathrm{s}^{-1}\right)$, ratio between internal and external $\mathrm{CO}_{2}$ concentrations $\mathrm{Ci} / \mathrm{Ca}$, and nocturnal respiration $\left(R_{\mathrm{n}}, \mu \mathrm{mol} \mathrm{CO}_{2} \mathrm{~m}^{-2} \mathrm{~s}^{-1}\right)$. The water use efficiency (WUE) was calculated as the ratio between $A$ and $E$. The parameters were measured using an infrared gas analyzer (IRGA, model LI6400xt, Li-Cor, Nebraska, EUA). The measurements of $A, g_{s}, E$, and $C_{i} / C_{a}$ were performed between 8:30 and 11:00 am under constant photosynthetically active radiation (PAR, $1000 \mu \mathrm{mol}$ photons $\left.\mathrm{m}^{-2} \mathrm{~s}^{-1}\right)$ and temperature $\left(25^{\circ} \mathrm{C}\right)$. For measuring $R_{\mathrm{n}}$, the leaves were dark-adapted for at least $3 \mathrm{~h}$, and the evaluation was performed after 10:30 pm. The respiration was assessed the night before photosynthetic measurements.

\section{Chlorophyll a fluorescence}

Chlorophyll $a$ fluorescence was measured in the same leaf of the photosynthesis using an IRGA, and images of chlorophyll a fluorescence were obtained using a modulated imagingPAM fluorometer (Heinz, Walz, Effeltrich, Germany). To obtain the images, the fluorescence signals at all examined points of the leaf area were captured by a CCD camera coupled to the device, which provided the images. The pixelvalue images of the fluorescence variables were displayed with the help of a color code ranging from black $(0.000)$ to pink (1.000). For the measurements, leaves were initially dark-acclimated for $40 \mathrm{~min}$ so that the reaction centers were fully opened to obtain the minimal $\left(F_{0}\right)$ and maximal chlorophyll fluorescence $\left(F_{\mathrm{m}}\right)$. From these values, the maximum photochemical efficiency of PSII $\left(F_{\mathrm{v}} / F_{\mathrm{m}}\right)$ was calculated according to Genty et al. (1989).

$F \mathrm{v} / F \mathrm{~m}=\frac{F \mathrm{~m}-F 0}{F \mathrm{~m}}$

After sample illumination, saturation pulses were applied to determine the light-acclimated variables: the quantum yield of photochemical energy conversion in PSII $\left(Y_{\| 1}\right)$, the quenching of regulated $\left(Y_{\mathrm{NPQ}}\right)$, and the non-regulated $\left(Y_{\mathrm{NO}}\right)$ non-photochemical dissipation. The $Y_{\|}$was also used to estimate the apparent electron transport rate (ETR, Bilger et al., 1995),

$E T R=Y \mathrm{II} \times P A R \times$ Aleaf $\times 0.5$

Where; PAR is the photon flux $\left(\mu \mathrm{mol} \mathrm{m} \mathrm{m}^{-2}\right)$ on the leaves, $A_{\text {leaf }}$ is the amount corresponding to the fraction of incident light absorbed by the leaves, and 0.5 is the excitation energy fraction directed to the PSII (Laisk and Loreto, 1996).

\section{Assessing photorespiration in vivo}

The rate of photorespiration was calculated using the gas exchange and chlorophyll fluorescence parameters according to Epron et al. (1995) and Valentini et al. (1995). For these calculations, the linear electron flow was assumed to be driven by the carboxylation and oxygenation of ribulose-1,5-bisphosphate (i.e., all other processes consuming light-driven electrons are negligible). Four electrons are required for each carboxylation or oxygenation cycle, and one $\mathrm{CO}_{2}$ molecule is released per every two oxygenation cycles by glycine decarboxylation in the photorespiration pathway. Thus, 


$$
\begin{gathered}
J \mathrm{t}=\frac{F \mathrm{~m}^{\prime}-F \mathrm{~s}}{F \mathrm{~m}} \times \mathrm{PAR} \times 0.454 \\
J \mathrm{c}=\frac{1}{3}[\mathrm{Jt}+8(A+\mathrm{Rm})] \\
J \mathrm{o}=\frac{2}{3}[\mathrm{Jt}-4(A+\mathrm{Rm})] \\
P R=\frac{[\mathrm{Jt}-4(A+\mathrm{Rm})]}{12}
\end{gathered}
$$

Where; $J_{\mathrm{T}}$ is the total rate of electron transport through PSII to photosynthesis and photorespiration; $\left(F \mathrm{~m}^{\prime}-F \mathrm{~s}\right) / F \mathrm{~m}^{\prime}$ is the quantum efficiency of linear electron flow through PSII; PAR is the photosynthetically active radiation (photon flow, $\mu \mathrm{mol}$ $\mathrm{m}^{-2} \mathrm{~s}^{-1}$ ) incident on the leaf; 0.454 represents the proportional quanta used by PSII centers (Melis et al., 1987), $J_{C}$ and $J_{0}$ are the electron costs attributable to the carboxylation and oxygenase RuBP reactions, respectively; $A$ is the net $\mathrm{CO}_{2}$ assimilation rate; $R_{\mathrm{m}}$ is the rate of mitochondrial respiration during the day; and $P_{R}$ is the rate of $\mathrm{CO}_{2}$ production by photorespiration. $R_{\mathrm{m}}$ was estimated using nocturnal respiration $\left(R_{n}\right)$ according to Larcher (1983) and Bai et al., (2008),

$R \mathrm{~m}=R \mathrm{n} \times \frac{Q 10^{\mathrm{Td}-\mathrm{Tn}}}{10}$

Where; $\mathrm{Q}_{10}=2.2 ; \mathrm{T}_{\mathrm{n}}$ is the leaf temperature at which $R_{\mathrm{n}}$ was measured, and $\mathrm{T}_{\mathrm{d}}$ is the leaf temperature at which $R_{\mathrm{m}}$ was calculated.

\section{Photosynthetic pigments}

Chlorophyll $a(\mathrm{Chl} a)$, chlorophyll $b(\mathrm{Chl} b)$, and total carotenoids (Carot) were measured according to Costa et al. (2014). Three leaf discs $\left(0.6 \mathrm{~cm}^{2}\right)$ were immersed in $5 \mathrm{~mL}$ of a dimethyl sulfoxide (DMSO) solution saturated with calcium carbonate and incubated at $65^{\circ} \mathrm{C}$ for $24 \mathrm{~h}$. Absorbance was measured at 665.1, 649.1, and $480.0 \mathrm{~nm}$ in a UV-VIS spectrophotometer (model 60S, Thermo Scientific, Madison, USA), and the concentrations were calculated according to Wellburn (1994) and expressed by the leaf area.

\section{Sugars, starch and proline content}

To determine the contents of total soluble sugars, reducing sugars, non-reducing sugars and starch, $200 \mathrm{mg}$ of leaf tissue were immersed in ethanol $80 \%$, heated for $30 \mathrm{~min}$ at $65^{\circ} \mathrm{C}$, and ground. The extract was centrifuged, and three washes of the pellet were collected in a new tube. The ethanolic extract (supernatant) was used to determine the total sugars, reducing sugars, and non-reducing sugars, and the pellet was used to determine the starch content. Total soluble sugars were quantified according to the phenolsulfuric method (DuBois et al., 1956) with a reading at 40 $\mathrm{nm}$. The results were calculated using a standard sucrose curve. Reducing sugars were determined according to the dinitrosalicylic acid method (Miller, 1959) at $540 \mathrm{~nm}$ using a standard glucose curve. The non-reducing sugars were calculated using the differences between the total soluble sugars and reducing sugars. For starch quantification, the solid residue from the extraction was dried in an oven at $65^{\circ} \mathrm{C}$ for $72 \mathrm{~h}$ and determined according to McCready et al., (1950). The absorbance was read at $490 \mathrm{~nm}$ and calculated using a standard sucrose curve. Absorbance measurements were read with a UV-VIS spectrophotometer, and the results were expressed in milligrams per gram of fresh matter $(\mathrm{mg}$ $\mathrm{g}^{-1}$ ). For the measurement of free proline expressed in $\mu \mathrm{mol}$ $\mathrm{g}^{-1} \mathrm{FW}, 0,2 \mathrm{~g}$ of fresh leaf material was used following the method of Bates et al. (1973).

\section{Rate of electrolyte leakage}

Leaf discs $\left(3 \mathrm{~cm}^{-2}\right)$ were immersed in ultrapure water, and the initial conductivity was measured after $24 \mathrm{~h}$. The samples were then kept at $100^{\circ} \mathrm{C}$ for $1 \mathrm{~h}$, and the final conductivity was evaluated. The electrical conductivity of the leaf sample was measured using a conductivity meter (CD-850 model, Instrutherm, Brazil), and the rate of electrolyte leakage (\%) was calculated according to Pimentel et al., (2002).

\section{Biometric analyses}

The plants were measured to determine their height $(H, m)$, number of nodes (NN) and stem diameter (SD, mm). Leaves and stems were separated, packed in paper bags, and dried in a forced air circulation oven $\left(65^{\circ} \mathrm{C}\right)$ for $2 \mathrm{~h}$ to obtain leaf dry matter (LDM, g) and stem dry matter (SDM, g). The leaf area $\left(\mathrm{LA}, \mathrm{m}^{2}\right)$ was measured using ImageJ software. The specific leaf area (SLA, $\left.\mathrm{m}^{2} \mathrm{~g}^{-1} \mathrm{LDM}\right)$ was calculated as the ratio between LA and LDM.

\section{Statistical analyses}

The experimental design involved a randomized block with a $3 \times 2$ factorial scheme (three soybean cultivars and two field capacities). The data were subjected to analysis of variance, and the means were compared by the Tukey test $\left({ }^{*} p \leq 0.05\right.$ and ${ }^{* *} p \leq 0.01$ ) using the Variance Analysis System (SISVAR, v. 5.4).

\section{Conclusion}

It could be concluded that $7739 \mathrm{M}$, Anta 82 and Desafio cultivars showed the similar performance under water deficit and high temperature for many parameters, such as the decrease in water and osmotic potential, photosynthetic rate, partition of electrons destined for photosynthesis and the increase of the electrolyte release. However, the cultivar Desafio demonstrated higher physiological stability and growth, potentially indicating double tolerance to these stresses. Thus, physiological traits such as gas exchange, chlorophyll $a$ fluorescence, photorespiration, and rate of electrolyte leakage are good indicators in the selection of tolerant soybean cultivars to combine to water deficit under high temperature.

\section{Acknowledgments}

The authors thank the National Council for Scientific and Technological Development (CNPq, grants no. 551456/20108 and 552689/2011-4) and the Goiano Federal Institute of Education, Science and Technology, Rio Verde campus (IFGoiano-RV, grants no. DPPG 044/2015) for providing financial support. JNC, CM, and GMA are grateful to the Coordination for the Improvement of Higher Education Personnel (CAPES) and CNPq for scholarships.

\section{References}


Apel K, Hirt H (2004) Reactive oxygen species: Metabolism, oxidative stress, and signal transduction. Annu Rev Plant Biol. 55:373-399.

Araújo SAC, Deminicis BB (2009) Fotoinibição da Fotossíntese [Photoinhibition of the Photosynthesis]. Rev Bras Biocienc. 7(4): 463-472.

Armada E, Azcón R, López-Castilho OM, Calvo-Polanco M, Ruiz-Lozano JM (2015) Autochthonous arbuscular mycorrhizal fungi and Bacillus thuringiensis from a degraded Mediterranean area can be used to improve physiological traits and performance of a plant of agronomic interest under drought conditions. Plant Physiol Biochem. 90: 64-74.

Arruda IM, Moda-Cirino V, Buratto OJS, Ferreira JM (2015) Growth and yield of peanut cultivars and breeding lines under water deficit. Pesq Agropec Bras. 45(2): 146-154.

Ashraf M, Harris PJC (2013) Photosynthesis under stressful environments: An overview. Photosynthetica. 51(2): 163190.

Bai J, Xu DH, Kang HM, Chen K, Wang G (2008) Photoprotective function of photorespiration in Reaumuria soongorica during different levels of drought stress in natural high irradiance. Photosynthetica. 46(2): 232-237.

Barrs HD, Weatherley PE (1962) A re-examination of the relative turgidity technique for estimating water deficits in leaves. Aust J Biol Sci. 15(3): 413-428.

Bates LS, Waldren RP, Teare ED (1973) Rapid determination of free proline for stress studies. Plant and Soil. 39: 205208.

Batista P F, Costa A C, Müller C, Silva-Filho RO, Silva FB, Merchant A, Mendes GC, Nascimento KJT (2018) Nitric oxide mitigates the effect of water deficit in Crambe abyssinica. Plant Physiol Biochem. 129: 310-322.

Bilger W, Schreiber U, Bock M (1995) Determination of the quantum efficiency of photosystem II and nonphotochemical quenching of chlorophyll fluorescence in the field. Oecologia. 102(4): 425-432.

Bolhar-Nordenkamf HR, Long SP, Baker NR, Lechner EG (1988) Chlorophyll fluorescence as a probe of the photosynthetic competence of leaves in the field: a review of current instrumentation. Funct Ecol. 3(4): 497-514.

Cardona T, Shao S, Nixon PJ (2018) Enhancing photosynthesis in plants: the light reactions. Essays Biochem. 62(1): 85-94.

Carmody M, Waszczak C, Idänheimo N, Saarinen T, Kangasjärvi J (2016) ROS signaling in a destabilized world: A molecular understanding of climate change. J Plant Physiol. 203: 69-83.

Carmo-Silva AE, Gore MA, Andrade-Sanchez P, French AN, Hunsaker DJ, Salvucci ME (2012) Decreased $\mathrm{CO}_{2}$ availability and inactivation of Rubisco limit photosynthesis in cotton plants under heat and drought stress in the field. Environ Exp Bot. 83: 1-11.

Carvalho MHC (2008) Drought stress and reactive oxygen species: production, scavenging and signaling. Plant signaling \& behavior, 3(3): 156-165.

Chaves MM, Costa JM, Zarrouk O, Pinheiro C, Lopes CM, Pereira JS (2016) Controlling stomatal aperture in semiarid regions: The dilemma of saving water or being cool?. Plant Sci. 251: 54-64.

CONAB (Companhia Nacional de Abastecimento) (2016) Acompanhamento da safra brasileira grãos [Monitoring of the Brazilian crop grains]. Acomp Safra Bras Grãos - Safra 2015/16. 3: 1-174.
Costa AC, Rosa M, Megguer CA, Silva FG, Pereira FP, Otoni WC (2014) A reliable methodology for assessing the in vitro photosynthetic competence of two Brazilian savanna species: Hyptis marrubioides and Hancornia speciosa. Plant Cell Tissue Organ Cult. 117(3): 443-454.

Cvikrová M, Gemperlová L, Martincová O, Vanková R (2013) Effect of drought and combined drought and heat stress on polyamine metabolism in proline-over-producing tobacco plants. Plant Physiol Biochem. 73: 7-15.

Dai A, Zhao T, Chen J (2018) Climate change and drought: a precipitation and evaporation perspective. Curr Clim Change Rep. 4: 301-312.

DaMatta FM, Ramalho JDC (2006) Impacts of drought and temperature stress on coffee physiology and production: a review. J Plant Physiol .18(1): 55-81.

Demming-Adams B, Adams WW, Barker DH, Logan BA, Bowling DR, Verhoeven AS (1996) Using chlorophyll fluorescence to assess the fraction of absorbed light allocated to thermal dissipation of excess excitation. Physiol Plant. 98(2): 253-264.

Ding L, Gao C, Li Y, Zhu Y, Xu G, Shen Q, Kaldenhoff R, Kai L, Guo $S$ (2015) The enhanced drought tolerance of rice plants under ammonium is related to aquaporin (AQP). Plant Sci. 234: 14-21.

Du W, Wang M, Fu S, Yu D (2009) Mapping QTLs for seed yield and drought susceptibility index in soybean (Glycine max L.) across different environments. J Genet Genomics. 36(12): 721-731.

DuBois M, Gilles KA, Hamilton JK, Rebers PA, Smith F (1956) Colorimetric method for determination of sugars and related substances. Anal Chem. 28(3):350-356.

Epron D, Godard D, Cornic G, Genty B (1995) Limitation of net $\mathrm{CO}_{2}$ assimilation rate by internal resistances to $\mathrm{CO}_{2}$ transfer in the leaves of two tree species (Fagus sylvatica L. \& Castanea sativa Mill.). Plant Cell Environ. 18(1): 43-51.

Fehr WR, Caviness CE (1977) Stages of soybean development. lowa State University Cooperative Extension Service, Special Report 80. $11 \mathrm{p}$.

Fernandes FBP, Lacerda CF, Andrade EM, Neves ALR, Sousa CHC (2015) Effect of soil management on water deficit, gas exchange and cowpea yield in the semi-arid region. Rev Ciên Agron. 46(3): 506-505.

Genty B, Briantais JM, Baker NR (1989) The relationship between the quantum yield of photosynthetic electron transport and quenching of chlorophyll fluorescence. Biochim Biophys Acta. 990(1): 87-92.

Gill SS, Tuteja N (2010) Reactive oxygen species and antioxidant machinery in abiotic stress tolerance in crop plants. Plant Physiol Biochem. 48(12): 909-930.

Goisser M, Geppert U, Rötzer T, Paya A, Huber A, Kerner R, Bauerle T, Pretzsch H, Pritsch K, Häberle KH, Matyssek R, Grams TEE (2016) Does belowground interaction with Fagus sylvatica increase drought susceptibility of photosynthesis and stem growth in Picea abies?. For Ecol Manage. 375: 268-278.

Gondim TMS, Cavalcante LF, Beltrão NEM (2010) Aquecimento global: Salinidade e consequências no comportamento vegetal [Global warming: Salinity and consequences on plant behavior]. Rev Bras Ol Fibros. 14: 37-54.

Greer DH (2015) Temperature-dependent responses of the photosynthetic and chlorophyll fluorescence attributes of apple (Malus domestica) leaves during a sustained high temperature event. Plant Physiol Biochem. 97: 139-146. 
Han JM, Meng HF, Wang SY, Jiang CD, Liu F, Zhang WF, Zhang YL (2016) Variability of mesophyll conductance and its relationship with water use efficiency in cotton leaves under drought pretreatment. J Plant Physiol. 194: 61-71.

Harsh A, Sharma YK, Joshi U, Rampuria S, Singh G, Kumar S, Sharma R (2004) Effect of short-term heat stress on total sugars, proline and some antioxidant enzymes in moth bean (Vigna aconitifolia). Ann Agric Sci. 61(1): 57-64.

Hasibeder R, Fuchslueger L, Richter A, Bahn M (2015) Summer drought alters carbon allocation to roots and root respiration in mountain grassland. New Phytol. 205(3): 1117-1127.

Hendrickson L, Furbank RT, Chow WS (2004) A simple alternative approach to assessing the fate of absorbed light energy using chlorophyll fluorescence. Photosynth Res. 82(1): 73-81.

Heschel MS, Evankow A, Wolfson KB, Carlson JE, Holsinger KE (2014) Drought response diversification in african Protea species. Int J Plant Sci. 175(4): 442-449.

Hetherington S, Smillie RM, Davies WJ (1998) Photosynthetic activities of vegetative and fruiting tissues of tomato. J Exp Bot. 49(324): 1173-1181.

Khan MN, Komatsu S (2016) Proteomic analysis of soybean root including hypocotyl during recovery from drought stress. J Proteomics. 144: 39-50.

Klughammer C, Schreiber U (2008) Complementary PS II quantum yields calculated from simple fluorescence parameters measured by PAM fluorometry and the saturation pulse method. PAM Application Notes. 1: 27-35

Kramer DM, Jhonson G, Kiirats O, Edwards GE (2004) New fluorescence parameters for the determination of QA redox state and excitation energy fluxes. Photosynth Res. 79(2): 209-218.

Kromdijk J, Głowacka K, Leonelli L, Gabilly S T, Iwai M, Niyogi KK, Long SP (2016) Improving photosynthesis and crop productivity by accelerating recovery from photoprotection. Science. 354(6314): 857-861.

Kumar KS, Dahms H, Lee J, Kim H, Lee WC, Shin K (2014) Algal photosynthetic responses to toxic metals and herbicides assessed by chlorophyll a fluorescence. Ecotox Environ Safe. 104: 51-71.

Laisk A, Loreto $F$ (1996) Determining photosynthetic parameters from leaf $\mathrm{CO}_{2}$ exchange and chlorophyll fluorescence. J Plant Physiol. 110(3): 903-912.

Larcher W (1983) Physiological Plant Ecology, Springer, Berlin.

Li YF, Wu Y, Hernandez-Espinosa N, Penã RJ (2013) Heat and drought stress on durum wheat: responses of genotypes, yield, and quality parameters. J Cereal Sci. 57(3): 398-404.

Lu T, Meng Z, Zhang G, Qi M, Sun Z, Liu Y, Li T (2017) Subhigh temperature and high light intensity induced irreversible inhibition on photosynthesis system of tomato plant (Solanum lycopersicum L.). Front Plant Sci. 8:365.

Lubovská Z, Dobrá J, Storchová H, Willhelmová N, Vankivá R (2014) Cytokinin oxidase/dehydrogenase overexpression modifies antioxidant defense against heat, drought and their combination in Nicotiana tabacum plant. J Plant Physiol. 171(17): 1625-1633.

Marcuzzo FFN, Cardoso MRD, Faria TG (2012) Chuvas no Cerrado da região Centro-Oeste do Brasil: análise histórica e tendência futura [Rain at Cerrado of Brazil Middle-West region: analysis historical and future trends]. Ateliê Geográfico. 6: 112-130.
Mathur S, Agrawal D, Jajjo A (2014) Photosynthesis: Response to high temperature stress. J Photochem Photobiol B. 137: 116-126.

McCready RM, Guggolz J, Silviera V, Owens HS (1950) Determination of starch and amylose in vegetables. Anal Chem. 22(9): 1156-1158.

Mckenzie-Gopsill AG, Lukens L, Lee E, Swanton CJ (2016) Does the presence of neighbouring weeds alter the expression of adaptive plasticity to subsequent drought stress in soybean? Field Crops Res. 192: 144-153.

Melis A, Spangfort M, Andersson B (1987) Light-absorption and electron-transport balance between photosystem II and photosystem I in spinach chloroplasts. Photochem Photobiol. 45(1): 129-136.

Messinger SM, Buckley TN, Mott KA (2006) Evidence for involvement of photosynthetic processes in the stomatal response to $\mathrm{CO}_{2}$. Plant Physiol. 140(2): 771-778.

Miller GL (1959) Use of dinitrosalicylic acid reagent for determination of reducing sugar. Anal Chem. 31(3): 426428.

Mishra D, Shekhar S, Agrawal L, Chakraborty S, Chakraborty N (2017) Cultivar-specific high temperature stress responses in bread wheat (Triticum aestivum L.) associated with physicochemical traits and defense pathways. Food Chem. 221: 1077-1087.

Monteiro JG, Cruz FJR, Nardin MB, Santos DMM (2014) Crescimento e conteúdo de prolina em plântulas de guandu submetidas a estresse osmótico e à putrescina exógena [Growth and proline content in pigeon pea seedlings subjected to osmotic stress and to exogenous putrescine]. Pesq Agropec Bras. 49: 18-25.

Moura LMF, Costa AC, Müller C, Silva-Filho RO, Almeida GM, Vital RG, Castro JN, Teixeira MB (2018) Drought tolerance in potential oilseed plants for biofuel production. Aust J Crop Sci. 12(2): 289-298.

Mundstock CM, Thomas AL (2005) Soja - Fatores que afetam o crescimento e o rendimento de grãos [Soybean - Factors affecting grain growth and yield]. The Federal University of Rio Grande do Sul, Porto Alegre.

Nankishore A, Farrell AD (2016) The response of contrasting tomato genotypes to combined heat and drought stress. J Plant Physiol. 202: 75-82.

Pask AJD, Pietragalla J, Mullan DM, Reynolds MP (2012) Physiological Breeding II: A Field Guide to Wheat Phenotyping. In: Pierre CS, Arce VT (eds.) Osmotic adjustment. CIMMYT, México. pp. 21-24.

Perdomo JA, Capó-Bauçà S, Carmo-Silva E, Galmés J (2017) Rubisco and rubisco activase play an important role in the biochemical limitations of photosynthesis in rice, wheat, and maize under high temperature and water deficit. Front Plant Sci. 8: 490.

Pimentel C, Sarr B, Diouf O, Abboud ACS, Macauley HR (2002) Tolerância protoplasmática foliar à seca, em dois genótipos de caupi cultivados em campo [Leaf protoplasmic tolerance to drought, in two cowpea genotypes cultivated at the field]. Rev Univer Rural Ciên Vid. 22(1): 07-14.

Pinheiro C, Chaves MM (2011) Photosynthesis and drought: can we make metabolic connections from available data? J Exp Bot. 62(3): 869-882.

Pintó-Marijuan M, Munné-Bosch S (2013) Ecophysiology of invasive plants: osmotic adjustment and antioxidants. Trends Plant Sci. 18(12): 660-666. 
Pradhan GP, Prasad PVV, Fritz AK, Kirkham MB, Gill BS (2012) Effects of drought and high temperature stress on synthetic hexaploid wheat. F Plant Biol. 39(3): 190-198

Qu L, Chen J, Dong G, Jiang S, Li L, Guo J, Shao C (2016) Heat waves reduce ecosystem carbon sink strength in a Eurasian meadow steppe. Environ Res. 144: 39-48.

Ramel F, Birtic S, Cuine SP, Triantaphylides C, Ravanat J, Havaux M (2012) Chemical quenching of singlet oxygen by carotenoids in plants. J Plant Physiol. 158: 1267-1278.

Ribas-Carbo M, Taylor NL, Giles L, Busquets S, Finnegan PM, Day DA, Lambers H, Medrano H, Berry JA, Flexas J (2005) Effects of water stress on respiration in soybean leaves. Plant Physiol. 139(1): 466-473.

Rizhsky L, Liang H, Shuman J, Shulaev V, Davletava S, Mittler $R$ (2004) When defense pathways collide. The response of Arabidopsis to a combination of drought and heat stress. Crop Sci. 134(4): 1683-1696.

Santos JI, Cesarin AE, Sales CAR, Triano MBB, Martins PFRB, Braga AF, Neto NJ, Barroso AAM, Alves PLCA, Huaman CAM (2017) Increase of Atmosphere $\mathrm{CO}_{2}$ Concentration and Its Effects on Culture/Weed Interaction. World Academy of Science, Engineering and Technology, International Journal of Biological, Biomolecular, Agricultural, Food and Biotechnological Engineering. 11(6): 419-426.

Silva EN, Ferreira-Silva SL, Viégas RA, Silveira JA (2010) The role of organic and inorganic solutes in the osmotic adjustment of drought-stressed Jatropha curcas plants. Environ Exp Bot. 69(3): 279-285.

Silva EN, Silveira JAG, Ribeiro RV, Vieira SA (2015) Photoprotective function of energy dissipation by thermal processes and photorespiratory mechanisms in Jatropha curcas plants during different intensities of drought and after recovery. Environ Exp Bot. 110: 36-45.

Szymańska R, Ślesak I, Orzechowska A, Kruk J (2017) Physiological and biochemical responses to high light and temperature stress in plants. Environ Exp Bot. 139: 165177.
Valentini R, Epron D, De Angelis P, Matteucci G, Dreyer E (1995) In situ estimation of net $\mathrm{CO}_{2}$ assimilation, photosynthetic electron flow and photorespiration in Turkey oak ( $Q$. cerris L.) leaves: diurnal cycles under different levels of water supply. Plant Cell Environ. 18:631640.

Vital RG, Jakelaitis A, Silva FB, Batista, PF, Almeida GM, Costa AC, Rodrigues AA (2017). Physiological changes and in the carbohydrate content of sunflower plants submitted to sub-doses of glyphosate and trinexapac-ethyl. Bragantia. 76(1): 33-44.

Wang R, Gao M, Ji S, Wang S, Meng Y, Zhou Z (2016) Carbon allocation, osmotic adjustment, antioxidant capacity and growth in cotton under long-term soil drought during flowering and boll-forming period. Plant Physiol Biochem. 107: 137-146.

Wellburn AR (1994) The spectral determination of chlorophylls a and $b$, as well as total carotenoids, using various solvents with spectrophotometers of different resolution. J Plant Physiol. 144(3): 307-313.

Wu S, Hu C, Tan Q, Nie Z, Sun X (2014) Effects of molybdenum on water utilization, antioxidative defense system and osmotic-adjustment ability in winter wheat (Triticum aestivum) under drought stress. Plant Physiol Biochem. 83: 365-374.

Zeeman SC, Smith SM, Smith AM (2007) The diurnal metabolism of leaf starch. Biochemical J. 401(1): 13-28.

Zhang T, Lin X, Sassenrath GF (2015) Current irrigation practices in the central United States reduce drought and extreme heat impacts for maize and soybean, but not for wheat. Sci Total Environ. 508:331-342.

Zuo J, Pullen S, Palmer J, Bennetts H, Chileshe N, Ma T (2015) Impacts of heat waves and corresponding measures: a review. J Clean Prod. 92:1-12. 